\title{
Nilai-Nilai Perdamaian dalam Buku Teks Pendidikan Agama Islam (Akhlak) di Sekolah Muhammadiyah ${ }^{1}$
}

DOI 10.18196/AIIJIS.2015. 0043. $41-65$

\author{
NURWANTO, MUHAMMAD AZHAR, MARSUDI, GHOFFAR ISMAIL \\ Fakultas Agama Islam \\ Universitas Muhammadiyah Yogyakarta
}

\begin{abstract}
The article examines whether the textbooks on Islamic Ethics (akhlak) taught in the Muhammadiyah schools promote peace. Studying the content of schools' text books is nececessary due to the increase of social conflicts and violent actions among students. In particular, this article explores the Islamic teaching of peace within Islamic Ethics textbooks published by the Board of Basic and Secondary Education of Muhammadiyah (DIKDASMEN) in Yogyakarta Special Territory. By the use of content analysis, this article finds that teaching materials in the Islamic Ethics textbooks promote the values of peace. However, the texbooks editing quality needs to be improved so that the narrratives (story tellings) and pictures (ilustration) can fit the students' needs..
\end{abstract}

Keywords: Peace; Textbook; Islamic Ethics; Muhammadiyah

\section{ABSTRAK}

Artikel ini membahas tentang apakah buku-buku mata pelajaran Akhlaq yang diajarkan di sekolah-sekolah Muhammadiyah mengandung nilai-nilai perdapaian atau tidak. Menghkaji isi buku-buku akhlaq saat ini penting untuk dilakukan seiring dengan meningkatkan konflik social dan aksi-kasi kekerasan di kalangan pelajar. Secara khusus, artikel ini menelaah secara mendalami ajaran-ajaran Islam tentang perdamaian dalam buku-buku mata pelajaran akhlaq yang dipublikasikan oleh Majelis Pendidikan Dasar dan menengah (DIKDASMEN) di Daerah Istimewa Yogyakarta. Dengan menggunakan analisis isi, artikel ini menemukan bahwa materimateri pelajaran Akhlaq mengandung dan mengkampanyekan nilai-nilai perdamaian. Meskipun demikian, mutu penyuntingan buku-buku tersebut perlu ditingkatkan sehingga narasi (kisah-kisah) dan gambar-gambar yang terdapat dalam buku tersebut dapat memenuhi kebutuhan siswa.

Kata kunci: perdamaian; buku teks; Akhlaq; Muhammadiyah 


\section{PENDAHULUAN}

Berdasarkan UU No. 20 Tahun 2003 tentang Sistem Pendidikan Nasional, tujuan pendidikan nasional bukan sekedar untuk mewujudkan insan yang cerdas dan terampil namun lebih dari itu membangun pribadi yang beriman dan bertaqwa kepada Tuhan Yang Maha Esa. Untuk mencapai tujuan ini ditetapkan Peraturan Menteri Pendidikan Nasional (Permendiknas) No. 22 Tahun 2006 tentang standar isi pendidikan yang menempatkan Kelompok Mata Pelajaran Pendidikan Agama dan Akhlak Mulia sebagai unsur yang harus ada dalam struktur kurikulum di setiap jenjang pendidikan. ${ }^{2}$ Mata pelajaran ini diadakan dalam rangka mengarahkan peserta didik untuk mencapai tujuan pendidikannya yakni menjadi pribadi yang cerdas, terampil dan berakhlak atau berperilaku yang mulia.

Kelompok Mata Pelajaran Agama dan Akhlak Mulia pada tingkat SMA MA misalnya, secara substantif meliputi ${ }^{3}$ : 1) berperilaku sesuai dengan ajaran agama yang dianut sesuai dengan perkembangan remaja; 2) menghargai keberagaman agama, bangsa, suku, ras dan golongan sosial-ekonomi dan budaya dalam tatanan global; 3) berpartisipasi dalam menegakkan aturanaturan sosial; 4) memahami hak dan kewajiban diri dan orang lain dalam pergaulan di masyarakat; 5) menghargai adanya perbedaan pendapat dan berempati terhadap orang lain; 6) berkomunikasi dan berinteraksi secara efektif dan santun melalui berbagai cara termasuk pemanfaatan teknologi informasi yang mencerminkan harkat dan martabatnya sebagai makhluk Tuhan; 7) menjaga kebersihan, kesehatan, ketahanan dan kebugaran jasmani dalam kehidupan sesuai dengan tuntutan agama; dan 8) memanfaatkan lingkungan sebagai makhluk ciptaan Tuhan secara bertanggung jawab.

Apa yang tertuang dalam tujuan pendidikan nasional dan ketentuan di atas ternyata berseberangan dengan fakta tentang potret buram sikap dan perilaku sosial siswa yang dalam berbagai kasus terjadi di masyarakat. Temuan Hasballah menunjukkan bahwa kekerasan di kalangan siswa di Jakarta sudah sedemikian mengkhawatirkan. Lebih detil ia menemukan bahwa tindak kekerasan yang dilakukan oleh para pelajar tersebut di antaranya berkorelasi dengan kondisi tempat tinggal yang tidak mendukung, kualitas hubungan dengan orang tua yang buruk dan konsep diri yang negatif. ${ }^{4}$ Lebih dari itu, salah satu catatan penting yang disampaikan Hasballah adalah bahwa sekolah terutama guru memang perlu mengembangkan pembelajaran yang demokratis termasuk di dalamnya materi-materi yang menggugah untuk berperilaku positif. Di antara materi yang penting tersebut adalah pandangan, ide dan nilai hidup 
yang harmonis dan mencintai perdamaian.

Kasus-kasus faktual yang lain seperti kekerasan kolektif yang dilakukan oleh sekelompok warga belajar di STPDN (Sekolah Tinggi Pemerintahan Dalam Negeri) hingga perkelahian antarsiswi yang tergabung dalam "Gank Nero" di daerah Jawa Barat serta tawuran antar-santri pesantren di Jawa Timur dalam dasawarsa terakhir ini merupakan bukti yang saling menguatkan tentang transfer nilai-nilai perdamaian yang lemah di masyarakat. Indikasi lainnya seperti vandalisme yang diwujudkan dalam aksi corat-coret dan pengrusakan fasilitas umum pun ikut memberi ukuran bahwa sensitivitas sosial di sebagian pelajar tidak terpola secara mulus. Sejumlah riset tentang bullying berupa kekerasan atau ejekan antar-siswa seperti mencubit, memukul, menyabet, mendorong, mengejek, mencolek dan menarik pakaian temannya menunjukkan gejala bahwa kebiasaan menghargai dan menyayangi orang lain masih bermasalah. Tentu saja, itu semua menjadi pekerjaan rumah bagi bagi orang tua, masyarakat dan lembaga pendidikan baik yang diselenggarakan oleh Pemerintah maupun masyarakat seperti Muhammadiyah.

Sekolah yang didirikan oleh Muhammadiyah, sebuah organisasi Muslim modernis di Indonesia, di antaranya telah menetapkan Pendidikan Agama yang disebut sebagai Al-Islam, Kemuhammadiyahan dan Bahasa Arab (ISMUBA) sebagai core dari pembinaan keimanan, ibadah dan akhlak. Secara khusus, berkenaan dengan Pendidikan Akhlak, konseptualisasi pendidikan perdamaian (peace education) dalam buku teks yang diterbitkan perlu didiskusikan. Persoalan warga belajar sebagaimana dijabarkan sebelumnya yakni berupa konflik antar warga belajar yang berakhir dengan intimidasi dan kekerasan dalam tahun-tahun terakhir ini juga terjadi dalam sekolah Muhammadiyah. Sehingga tantangan tersebut perlu direspons secara proaktif dalam kurikulum serta praktek pembelajaran yang sesuai dengan semangat hidup damai. Pertanyaan awal yang bisa diajukan adalah apakah kurikulum atau secara spesifik bahan ajar Pendidikan Akhlak di sekolah Muhammadiyah sebagai sebuah kasus sudah mengakomodasi pengetahuan dan nilai-nilai properdamaian? Berdasarkan persoalan tersebut, tulisan ini secara sistematis menjabarkan kerangka konseptual pendidikan nilai-nilai perdamaian, telaah atas muatan Pendidikan Akhlak dalam buku teks yang diterbitkan oleh Majelis Dikdasmen Pimpinan Wilayah Muhammadiyah di Daerah Istimewa Yogyakarta dan sejumlah masukan untuk perbaikan muatan buku teks tersebut. 


\section{TINJAUAN PUSTAKA}

Harber dan Sakade 5 telah menemukan bahwa sejumlah sekolah telah secara potensial maupun nyata menjadi bagian dari unit sosial yang melanggengkan kekerasan. Bentuk kekerasan yang nyata itu misalnya hukuman fisik (corporal punishment) di kelas dan yang bersifat potensial misalnya model pembelajaran yang indoktrinatif yang kurang atau tidak memberi kebebasan berpendapat. Pandangan Harber ini sejalan dengan pandangan Davies ${ }^{6}$ yang menyatakan bahwa sekolah, yang di antaranya ia sebut sejumlah Madrasah di Afganistan mengajarkan kekerasan dan terorisme. Selanjutnya, Davies merekomendasikan tentang perlunya pendidikan untuk melawan bentuk-bentuk terorisme atau apa yang ia sebut sebagai educating against extremism. ${ }^{7}$ Melalui kajian kasus, Harber dan Sakade menunjukkan bahwa sekolah-sekolah formal yang syarat dengan intelektualisme itu kerapkali berbeda dengan upaya-upaya non-formal. Keduanya mengkaji sebuah program pendidikan perdamaian di Birmingham, Inggris yang bertajuk West Midlands Quaker Peace Education Project (WMQPEP). Projek ini telah secara mendasar mendidik tentang suasana dan interaksi belajar yang humanis dan non-kekerasan dibandingkan dengan sekolah formal yang penuh dengan tekanan mental untuk menguasai materi dan bayang-bayang ujian nasional serta ancaman untuk tidak naik kelas.

Pelanggengan mind-set kekerasan, bias gender dan ketidakadilan juga ditemukan dalam praktek pendidikan di Indonesia. Muthaliin ${ }^{8}$ menemukan adanya konten bias gender dan diskriminasi dalam buku-buku teks SD. Beberapa buku teks Pendidikan Bahasa Arab di sekolah atau madrasah misalnya menampilkan contoh teks yang berbunyi: "daraba Ahmadu kalban" (Ahmad memukul anjing). Meskipun teks itu dimaksudkan untuk mengantarkan siswa agar memahami strukur kalimat dalam bahasa Arab, intensitas bacaan dan pemahaman tentu berkaitan juga dengan isi kalimatnya. Dikhawatirkan, pembacaan yang secara intensif tentang teks-teks serupa di atas akan mempengaruhi alam bawah sadar bahwa "memukul binatang" itu lazim untuk dilakukan. Riset Nurwanto ${ }^{9}$ juga menemukan bahwa sejumlah buku teks AlIslam yang diterbitkan oleh Majelis Dikdasmen PP Muhammadiyah mengandung muatan ketidakadilan gender dan memuat stereotype melalui, misalnya, foto yang tersaji bahwa laki-laki menyukai tawuran, tanpa disertai dengan penjelasan yang memadai dalam teks yang ditulis. Dengan demikian, penyajian tulisan yang utuh (koheren) dan terklarifikasi merupakan bahan ajar penting yang perlu disusun.

Pengembangan bahan ajar Al-Islam bermuatan perdamaian tentu memiliki 
dasar argumen. Khan ${ }^{10}$ secara analitis melakukan kajian teks dan ajaran Nabi Muhammad SAW bahwa kekerasan dan terorisme tidak memiliki akar keislaman (theologically baseless). Senada juga dikaji oleh Köylü ${ }^{11}$ bahwa ajaran tentang perdamaian sejatinya dapat ditemukan dalam esensi teks-teks keagamaan. Di sini, Köylü merekomendasikan tentang perlunya kontribusi sarjana Muslim untuk mendidik nilai-nilai perdamaian dengan berakar pada ajaran Islam itu sendiri. Oleh karena itu, kekayaan ide, nilai dan praktek historis Muslim merupakan bahan penting untuk konstruksi bahan ajar Al-Islam yang berorientasi perdamaian. Lebih dari itu, pengayaan dari sumber, literatur dan pengalaman praksis tentang perjuangan menegakkan perdamaian dari manapun merupakan sumber lainnya untuk mengembangkan bahan ajar berorientasi perdamaian. Atas dasar ini, tulisan ini merupakan upaya mengungkap peta kajian tentang seberapa jauh buku teks keagamaan, terutama keislaman, yang ada di sekolah Muhammadiyah yang mendasarkan pada ideide dan nilai-nilai perdamaian.

\section{KERANGKA TEORI}

a. Perdamaian

Kata 'damai' sering dimaknai sebagai situasi tanpa perang. Padahal, menurut de Rivera ${ }^{12}$ dan Fell ${ }^{13}$, kata ini dapat ditinjau dari dua sisi. Pertama adalah perdamaian negatif (negative peace). Sudut pandang ini persis dengan definisi sebagai situasi tanpa perang (war), pemerkosaan (rape), pembunuhan (homicide) atau kekerasan (violence). Sudut pandang kedua adalah damai positif (positive peace), yakni tumbuhnya kesamaan hak, harapan hidup yang panjang dan berbagai indikator keadilan. Sebagaimana mengutip pendapat Galtung (1969), de Rivera juga menyebut bahwa perang dan pembunuhan merupakan bentuk-bentuk kekerasan yang bersifat langsung (direct violence) sedangkan yang kedua, seperti persamaan hak dan keadilan, dapat menjadi kekerasan tidak langsung (indirect violence) apabila tidak diperjuangkan dan diwujudkan. Berpijak pada konsep ini, kemiskinan misalnya, merupakan bentuk kekerasan tidak langsung. Dengan demikian, konsep 'damai' perlu didefinisikan secara menyeluruh, mulai dari keadaan tanpa perang hingga keberlangsungan keadilan di tengah masyarakat.

b. Nilai-Nilai Perdamaian

Nilai-nilai perdamaian yang dimaksud dalam kajian ini adalah prinsip-prinsip atau standar perilaku (principles or standards of behaviour) yang dianggap penting atau berguna ${ }^{14}$, berkaitan dengan perdamaian. Dengan mengacu pada 
definisi 'damai' baik negatif maupun positif, nilai-nilai yang mendasari atau berkaitan dengan pembangunan perdamaian meliputi berbagai kondisi dan karakter yang perlu diwujudkan.

Secara sistematis, de Rivera ${ }^{15}$ menuangkan gagasannya mengenai hal-hal apa saja yang dapat dijadikan ukuran untuk menilai apakah suatu kondisi itu damai atau tidak. Ada 3 (tiga) kerangka besar bagaimana perdamaian itu berada, yakni: norma-norma sosial, struktur negara atau stabilitas politik dan karakteristik lingkungan. Ketiga kerangka ini dapat dijabarkan ke dalam 8 (delapan) isu penting sebagaimana diuraikan di bawah ini.

1) Norma-norma sosial

a) Tumbuhnya pendidikan perdamaian (peace education) yang meliputi kerjasama (cooperation) serta resolusi konflik melalui dialog, negosiasi dan relasi nir-kekerasan di antara warga.

b) Penghargaan terhadap kaum wanita dengan segala aktivitasnya atau adanya keadilan gender.

c) Tumbuhnya pemahaman, toleransi, solidaritas dan kewajiban yang sama untuk mencapai ikatan sosial (social cohesion) yang lebih baik serta mengurangi tumbuhnya permusuhan.

2) Konstruksi struktur negara dan stabilitas politik

a) Tumbuhnya partisipasi masyarakat yang lebih demokratis di antaranya dengan keberadaan masyarakat sipil yang mampu memperjuangkan kebutuhan-kebutuhan warganya.

b) Tumbuhnya komunikasi yang terbuka dan ditandai dengan prinsip transparansi dan akuntabilitas (pertanggung-jawaban).

c) Penjaminan terhadap hak-hak asasi manusia berikut dengan pengakuan nyata terhadap berbagai kelompok yang berbeda-beda (inclusion of all groups).

3) Karakteristik lingkungan

a) Tumbuhnya keamanaan sosial—baik lokal maupun internasional—dari pada menyulut perebutan kekuasaan dan persaingan persenjataan.

b) Penguatan pembangunan berkelanjutan (sustainable development) yang mementingkan harmoni dengan lingkungan.

Sementara itu, Fell ${ }^{16}$ menunjukkan beberapa nilai yang perlu diajarkan pada peserta didik untuk menumbuhkan karakter damai, di antaranya:

a. Afirmasi (affirmation) yaitu pengakuan dan penghargaan yang terbuka atas berbagai kekuatan dan potensi yang ada pada setiap pribadi atau 
kelompok.

b. Komunikasi (communication) yaitu kemampuan untuk tidak hanya menyampaikan ide kepada orang lain secara lisan atau tulisan, tetapi termasuk di dalamnya juga keterampilan untuk mendengarkan ${ }^{17}$.

c. Kerjasama (cooperation) yaitu bekerja bersama untuk mencapai tujuan yang sama, berbagi wawasan dan temuan serta melangkah bersama untuk mengurangi iklim kompetisi dan hirarki dalam hubungan sosial.

d. Resolusi konflik (conflict resolution) yakni pemecahan atas sengketa di masyarakat melalui jalan damai; bukan kekerasan.

Selain yang dikemukakan de Ravera dan Fell di atas, keterampilan hidup bermasyarakat juga perlu didukung dengan nilai-nilai, seperti empati, kepedulian dan kemandirian sebagai wujud kebiasaan-kebiasaan positif untuk menciptakan karakter damai. ${ }^{18}$ Oleh karena itu, dengan mencermati kerangka teori secara umum di atas, nilai-nilai perdamaian dapat berkaitan dengan aspek psikologisindividual seperti pemahaman (understanding) dan kemandirian; aspek sosiokultural seperti empati, komunikasi, kerjasama dan relasi tanpa kekerasan; serta aspek struktur-politik seperti penegakkan HAM dan keadilan atas semua warga. Penjelasan ini pada akhirnya mengasumsikan bahwa nilai-nilai dan ide-ide tentang perdamaian memerlukan kontribusi individu-individu berkarakter damai, relasi sosial yang mengutamakan perdamaian serta peran Negara dalam penanganan pembangunan berbasis pada kesejahteraan dan keadilan.

\section{METODE PENELITIAN}

Penelitian pustaka (library research) ini dimaksudkan untuk mengungkap muatan perdamaian, baik positive peace maupun negative peace, yang ada dalam buku teks resmi yang diterbitkan oleh Majelis Pendidikan Dasar dan Menengah Pimpinan Wilayah Muhammadiyah Daerah Istimewa Yogyakarta. Dengan menggunakan analisis isi (content analysis) terhadap buku-buku teks Pendidikan Akhlak sebagai bagian dari Mata Pelajaran Al-Islam yang diajarkan di sekolah Muhammadiyah di Yogyakarta, tulisan ini secara khusus mengupas buku teks Pendidikan Akhlak Kelas 10, 11 dan 12 SMA/MA/SMK Muhammadiyah. Selanjutnya, pemaparan analisisnya disajikan berdasarkan kategori isu yang berkaitan dengan nilai-nilai perdamaian (negative atau positive) sebagaimana yang telah dikonseptualisasi dalam teori maupun temuan yang ada dalam muatan buku-buku teks tersebut. 


\section{Acuan Kurikulum Mata Pelajaran Pendidikan Akhlak}

Bahan ajar Akhlak mengacu pada Kurikulum ISMUBA (AI-Islam, Kemuhammadiyahan dan Bahasa Arab) di sekolah dan madrasah Muhammadiyah. Saat ini, Kurikulum yang diberlakukan merupakan produk keputusan Majelis pada 2012. Sekolah dan madrasah Muhammadiyah di Yogyakarta mengacu pada Kurikulum 2012 yang diterbitkan oleh Majelis Pendidikan Dasar dan Menengah Pimpinan Wilayah Muhammadiyah Daerah Istimewa Yogyakarta tersebut. Berdasarkan telaah atas Standar Nasional Pendidikan (SNP) ${ }^{19}$, Kurikulum ISMUBA 2012 tetap mengacu, paling tidak, pada Standar Kompetensi Lulusan (SKL) dan Standar Isi yang dikeluarkan oleh Kementerian Pendidikan Nasional pada 2005 dan, selanjutnya, Majelis mengembangkan standar yang telah ada berdasarkan karakteristik lembaga pendidikan Muhammadiyah.

Produk Kurikulum ISMUBA 2012, di samping mengacu pada Kurikulum Nasional 2006 atau sering disebut sebagai Kurikulum Tingkat Satuan Pendidikan (KTSP), juga mengacu pada framework pendidikan Muhammadiyah. Hal ini, di antaranya, tampak pada bagian tertentu dari visi pendidikan Muhammadiyah yang menjelaskan visinya di antaranya: "... sebagai perwujudan tajdid dakwah amar maruf nahi munkar."20 Sedangkan misinya, di antaranya, adalah untuk" ...f. membentuk kader persyarikatan, ummat dan bangsa yang ikhlas, peka, peduli dan bertanggung jawab terhadap kemanusiaan dan lingkungan. "21

Kerangka misioner pendidikan di atas menunjukkan adanya upaya sinkronisasi nilai-nilai keagamaan dalam sudut pandang gerakan Muhammadiyah dengan pendidikan sebagai bidang aktivitasnya. Sebagaimana diketahui, di antara bidang-bidang yang lain seperti dakwah-keagamaan, sosial dan ekonomi, bidang pendidikan dianggap sebagai lahan primadona untuk penyemaian kader. Pendidikan dapat dianggap sebagai medan kultural yang dikelola paling rapi di lembaga yang biasa disebut sebagai gerakan Islam modernis ini. Upaya menjadikan lembaga pendidikannya sebagai 'perwujudan tajdid dakwah' dan pembentukan 'kader persyarikatan' merupakan acuan penting mengenai bagaimana kreativitas lokal Muhammadiyah ini disemaikan dan dikembangkan lebih jauh dari SNP sebagai acuan minimal yang telah diundangkan oleh Pemerintah.

Di samping itu, Majelis menetapkan tujuan pendidikan ISMUBA. Satu dari sekian tujuannya yang berkaitan dengan dimensi akhlak adalah:

" ... b. mewujudkan manusia Indonesia yang taat beragama dan berakhlakul karimah, yaitu manusia yang berpengetahuan, rajin beribadah, 
cerdas, produktif, kreatif, inovatif, jujur, adil, etis, bersidiplin, bertoleransi (tasamuh), menjaga keharmonisan secara personal dan sosial serta mengembangkan budaya islami dalam komunitas sekolah/madrasah sesuai Al-Qur'an and As-Sunnah. "22

Kutipan di atas, secara eksplisit menunjukkan nilai-nilai keagamaan yang hendak diajarkan kepada peserta didik. Secara kategoris, nilai-nilai seperti: berpengetahuan, rajin beribadah, cerdas, produktif, kreatif, inovatif, jujur, adil, etis dan berdisiplin merupakan kategori akhlak yang bersifat personal. Sedangkan nilai-nilai seperti: bertoleransi, harmoni personal dan sosial serta budaya Islami dalam komunitas merupakan contoh sikap sosial. Pembedaan sikap menjadi dua seperti ini dikenal dalam Kurikulum 2013 yang menyatakan bahwa dimensi sikap meliputi 'sikap spiritual' yang berdimensi personal dan 'sikap sosial' menyangkut relasi pribadi dengan orang lain, komunitas dan lingkungannya. ${ }^{23}$

Nilai-nilai dalam tujuan pendidikan ISMUBA di atas mengindikasikan adanya potensi untuk mengarahkan siswa pada sudut pandang damai yang bersifat positif (positive peace). ${ }^{24}$ Sikap jujur, adil, bertoleransi, harmoni personal dan sosial serta budaya Islami dalam komunitas merupakan elemen penting bagaimana budaya damai itu dibangun. Secara teoretik, kaitan antar-nilai ini menarik, misalnya damai dan kemiskinan (sebagai wujud dari ketidakadilan). Dalam pandangan Gandhi, perdamaian bukan sekedar karena nir-perang namun masyarakat yang bebas dari kemiskinan, sehingga keadilan sosial dapat tercipta. Singkatnya, harmoni dan rasa damai mudah tercipta bila kesenjangan sosial ekonomi teratasi. Itulah mengapa peraih nobel perdamaian asal Bangladesh, Muhammad Yunus, disebabkan perannya dalam mengentaskan kemiskinan secara nyata.

Di tengah upaya pendidikan karakter yang digulirkan Pemerintah, dokumen Kurikulum Majelis menyebutkan sekitar 40 nilai yang perlu dikembangkan di sekolah Muhammadiyah, yakni:

"... berpihak pada mustadl'afin dan dlu'afa, berpikiran maju, bersahaja, bertanggung jawab, bijak, damai, dinamis, disiplin, hemat, kasih sayang, kebahagiaan, kebebasan, kebersihan, keikhlasan, kejujuran, kerjasama, kesederhanaan, keseimbangan (tawasuth atau moderat), keteladanan, komitmen, kreatif, layanan, loyalitas, membaca, menghargai, nasionalisme, pembaharuan (tajdid), percaya diri, persatuan, proaktif, qanaah, rendah hati, sabar dan bersyukur, santun, sikap kritis, suka beramal saleh, teliti dan cermat, toleransi dan ulet." 
Sebagian besar nilai di atas tampak sesuai dengan semangat perdamaian. Hal penting selanjutnya yang perlu dikaji adalah seperti apa rumusannya dalam dokumen kurikulum terutama silabus dan penuangannya dalam bahan ajar atau buku teks. Penuangan nilai-nilai perdamaian dalam buku teks, secara teoretik, dapat berupa materi tersendiri ataupun terintegrasi dengan tema atau kajian yang telah ada.

Setelah mengkaji, visi, misi, tujuan dan nilai-nilai yang dijadikan fondasi pendidikan ISMUBA, terutama yang berkaitan dengan pembelajaran Akhlak, telaah terhadap SKL dan Standar Isi dalam silabus menjadi penting. Kajian terhadap hal tersebut setidaknya dapat memotret kedalaman dan keluasan bahan ajar yang berkaitan erat dengan isu perdamaian.

SKL merupakan kriteria mengenai kualifikasi kemampuan yang meliputi sikap, pengetahuan dan keterampilan, ${ }^{25}$ yang dicapai pada suatu jenjang pendidikan tertentu. Sebagaimana telah diurakan di awal tulisan ini, SKL ISMUBA — termasuk di dalamnya Pendidikan Akhlak—didasarkan pada SKL dalam Kurikulum 2006 versi Pemerintah melalui Badan Standar Nasional Pendidikan (BSNP), yang kemudian dikembangkan dengan standar pendidikan keislaman di Muhammadiyah. Dari 6 (enam) SKL materi Al-Islam, ada 1 (satu) SKL yang berkenaan dengan materi Akhlak. SKL tersebut menunjukkan kemampuan siswa untuk " ... 3. berperilaku terpuji seperti husnudzon, taubat, raja', adil dan menghargai karya orang lain dan meninggalkan perilaku tercela seperti isyrof, tabzir, ghibah dan fitnah."26

Dua sikap yang ditunjukkan dalam SKL di atas yang sejalan dengan pendidikan perdamaian adalah: pertama, sikap personal yang meliputi husnudzon atau berprasangka baik (positive thinking) serta, kedua, sikap sosial yang meliputi berbuat adil, mengindari ghibah (membicarakan dan mencemooh keburukan orang lain) dan menghindari fitnah (menuduh orang lain berbuat buruk tanpa bukti yang bisa dipertanggungjawabkan). Dalam SKL ini, sebagaimana dalam kajian de Rivera dan Fell, ${ }^{27}$ husnudzon dan adil dapat dikategorikan sebagai positive peace sedangkan menghindari ghibah dan fitnah merupakan kategori negative peace. Kedua-duanya tetap memiliki makna penting untuk pendidikan dan pembangunan perdamaian. Dengan demikian, SKL yang ditunjukkan dalam materi Akhlak ini berpotensi mengarahkan pada suatu budaya atau, paling tidak, situasi kelas yang berorientasi damai.

Secara teoretik, dengan mengacu pada desain Kurikulum 2006, SKL turunkan dan dijabarkan ke dalam Standar Kompetensi (SK). Masing-masing SK 
dijabarkan ke dalam Kompetensi Dasar (KD). ${ }^{28}$ Selanjutnya, di bawah ini dituangkan SK berikut dengan KD yang relevan dengan semangat perdamaian berdasarkan level kelas sebagai berikut:

\section{Tabel 1: Standar Kompetensi dan Kompetensi Dasar Materi Akhlak}

\begin{tabular}{|c|c|c|}
\hline KELAS/SEMESTER & STANDAR KOMPETENSI & KOMPETENSI DASAR (TELAH DIPILIH) \\
\hline $\mathrm{X} /$ Gasal & $\begin{array}{l}\text { 1. Terbiasa sifat-sifat } \\
\text { terpuji kepada diri } \\
\text { sendiri }\end{array}$ & $\begin{array}{l}\text { 1.1. Membiasakan sikap mujahadah an-nafsi/pengendalian diri }(p) \\
\text { 1.2. Membiasakan perilaku husnudzan }(p) \\
\text { 1.3. Membiasakan perilaku ukhuwah }(p) \\
\text { 1.4. Terbiasa diri berlaku intiqod (introspeksi) }(p) \\
\text { 1.6. Terbiasa diri berlaku ikhlas }(p) \\
\text { 1.9. Terbiasa diri bersikap menghargai karya orang lain }(p) \\
\text { 1.10. Terbiasa diri berlaku ishlah ( } p)\end{array}$ \\
\hline X/Genap & $\begin{array}{l}\text { 2. Menghindari akhlak } \\
\text { tercela kepada diri } \\
\text { sendiri }\end{array}$ & $\begin{array}{l}\text { 2.1. Terbiasa menjauhkan diri dari sifat iri dan dengki }(n) \\
\text { 2.2. Terbiasa menghindari sifat suudzan }(n) \\
\text { 2.3. Terbiasa menghindari sifat khianat }(n) \\
\text { 2.4. Terbiasa menghindari sifat dhalim }(n) \\
\text { 2.5. Terbiasa menghindari sifat ghodlob ( } n \text { ) } \\
\text { 2.6. Terbiasa menghindari sifat pelanggaran HAM dalam Islam (n) }\end{array}$ \\
\hline XI/Gasal & $\begin{array}{l}\text { 1. Terbiasa sifat-sifat } \\
\text { terpuji kepada Allah } \\
\text { dan Rasul }\end{array}$ & 1.9. Terbiasa diri berlaku meneladani Rasul (p) \\
\hline XI/Genap & $\begin{array}{l}\text { 2. Membiasakan } \\
\text { berperilaku terpuji } \\
\text { kepada orang lain } \\
\text { b. Menghindari akhlak } \\
\text { tercela kepada } \\
\text { sesama dan } \\
\text { lingkungan sekitar }\end{array}$ & $\begin{array}{ll}\text { a. } & \text { Terbiasa berperilaku toleransi dalam kehidupan ( } p \text { ) } \\
\text { b. } & \text { Terbiasa berperilaku terpuji dalam kerukunan hidup umat } \\
\text { c. } & \text { Meragama }(p) \\
& (p) \\
\text { a. } & \text { Menghiasakan perilaku persatuan dan kesatuan dalam masyarakat } \\
\text { b. } & \text { Terbiasa mengindari sifat al-qatl }(n) \\
\text { c. } & \text { Terbiasa menghindari sifat durhaka }(n) \\
\text { d. } & \text { Terbiasa menghindari sifat takabur }(n)\end{array}$ \\
\hline XII/Gasal & $\begin{array}{l}\text { 1. Terbiasa sifat-sifat } \\
\text { terpuji kepada } \\
\text { sesama dan } \\
\text { lingkungan sekitar }\end{array}$ & $\begin{array}{l}\text { 1.1. Terbiasa berperilaku kritis, demokratis dan fokus dalam kehidupan } \\
\text { sehari-hari }(p) \\
\text { 1.2. Terbiasa bertata-krama yang baik terhadap ayah-ibu dan guru }(p) \\
\text { 1.3. Terbiasa berperilaku terpuji dalam pergaulan terhadap pria dan } \\
\text { wanita secara islami }(p) \\
\text { 1.4. Terbiasa berperilaku terpuji terhadap orang yang lebih tua dan } \\
\text { lebih muda }(p) \\
\text { 1.5. Terbiasa berperilaku terpuji terhadap anak yatim, fakir dan miskin (p) } \\
\text { 1.6. Terbiasa berperilaku terpuji: adil dalam kehidupan sehari-hari }(p) \\
\text { 1.7. Terbiasa berperilaku terpuji: ridlo dalam kehidupan sehari-hari }(p) \\
\text { 1.8. Terbiasa berperilaku terpuji terhadap lingkungan sekitar }(p)\end{array}$ \\
\hline XII/Genap & $\begin{array}{l}\text { 2. Membiasakan } \\
\text { perilaku terpuji } \\
\text { terhadap sesama } \\
\text { 3. Membiasakan } \\
\text { perilaku terpuji } \\
\text { terhadap sesama }\end{array}$ & $\begin{array}{l}\text { 2.2. Terbiasa menghindari fitnah dan menggunjing }(n) \\
\text { 2.3. Terbiasa menghindari berbuat kerusakan }(n) \\
\text { 2.4. Terbiasa menghindari perampasan hak orang lain }(n) \\
\text { 3.1. Terbiasa saling menasehati dan berbuat baik }(p) \\
\text { 3.2. Terbiasa berperilaku terpuji dalam ber-musyawarah }(p) \\
\text { 3.3. Terbiasa berperil aku terpuji dalam bermusyawarah untuk } \\
\text { menyelesaikan masalah dan hidup berdemokrasi }(p)\end{array}$ \\
\hline \multicolumn{3}{|c|}{ Tabel 1 menampilkan sekian banyak konsep atau kata kunci (keyword) } \\
\hline
\end{tabular}


positive peace dan 13 terma negative peace yang tampak dari keseluruhan kelas. Kata kunci 'meneladani Rasul' sengaja dimasukkan sebagai inspirasi sikap hidup damai dengan mendasarkan pada kajian Khan bahwa Rasul, terutama Muhammad SAW' merupakan pembawa sikap damai. ${ }^{29}$ Ini berarti bahwa muatan pendidikan perdamaian (peace education) lebih dominan dibandingkan dengan peace building yakni pembangunan perdamaian yang diarahkan pada situasi tanpa perang, kekerasan, fitnah, perampasan hak dan praktek-praktek negatif lainnya. Biasanya, praktek sosial negatif seperti ini secara aktual terjadi di tengah masyarakat yang sudah tidak mengindahkan nilai-nilai dan hak-hak kemanusiaan. Perang misalnya, adalah wujud 'penghalalan' atas darah manusia yang sangat dihormati dalam masyarakat yang beradab. Sedangkan peace education diarahkan dalam rangka pencegahan dan sustainability kondisi damai yang telah tercipta di suatu masyarakat atau komunitas tertentu. Dengan demikian dapat dikatakan bahwa semua kelas di level SMAMMA, kecuali kelas XI Semester Gasal, secara eksplisit mengajarkan sikap apa saja yang perlu dihindari dan yang perlu diterapkan untuk menegakkan perdamaian.

\section{Muatan Perdamaian dalam Buku Teks}

Apa yang tertuang dalam SK dan KD, yang biasanya menjadi dasar penyusunan silabus, tidak sepenuhnya menggambarkan buku teks. Begitu juga sebaliknya, buku teks yang ada belum tentu secara komprehensif menguraikan kompetensi yang diharapkan. Meski demikian, SK, KD dan silabus tersebut dapat dijadikan sebagai acuan penyusunan buku teks. Oleh karena itu, dalam kajian berikut ini, akan dideskripsikan dan dianalisis muatan (content analysis) buku teks yang menjadi pegangan guru PAl ketika mereka mengajarkan materi Akhlak di jenjang SMA/MA di Yogyakarta. Di samping itu, analisis terhadap isi buku teks tersebut ditelaah berdasarkan kerangka pikir de Rivera dan Fell tentang negative peace dan positive peace. Di samping itu, pandangan Mahatma Gandhi bahwa kemiskinan sebagai penyubur kekerasan menjadi dimensi penting dalam pengerangkaan teori mengenai perdamaian. Damai bukan sekedar kondisi nir-perang atau kekerasan namun juga kondisi yang memungkinkan kebersamaan, keadilan dan kesejahteraan itu diupayakan untuk diwujudkan. Pandangan de Rivera lainnya bahwa nilainilai perdamaian dapat diteropong dari aspek pendidikan perdamaian (peace education), struktur politik (intervensi Negara) dan lingkungan aman (social 
security) juga dijadikan landasan telaah dalam tulisan ini. Selanjutnya, dalam tulisan ini, buku teks pada setiap kelas akan dikaji dan dianalisis.

\section{Buku Teks Akhlak Kelas 10}

Sistematika kajian dalam buku teks ini meliputi latar belakang (serambi), uraian konsep berikut dengan dalil-dalil naqli (Al-Qur'an dan al-Hadis) dan kisah yang berkaitan dengan materi. Namun demikian, secara tidak konsisten muncul berkenaan dengan gambar yang dicantumkan. Ada gambar yang dicantumkan sumbernya dan ada yang tidak, padahal itu jelas berasal dari internet. Selain itu, beberapa gambar yang ditampilkan tidak dikaitkan dengan penjelasan tertentu dalam suatu kalimat atau paragraf sehingga pemaknaan yang terkandung dalam gambar berpeluang menimbulkan tafsir ganda. Misalnya gambar tentang dua anak yang berkelahi yang tidak disertai dengan sumber gambar dan maksud dari gambar tersebut. ${ }^{30}$ Meskipun gambar tersebut terdapat dalam pembahasan tentang pengendalian diri tetapi maksud gambar perlu dijelaskan. Oleh karena itu, pilihan gambar perlu diuraikan atau dikaitkan dengan penjelasan karena dapat menjadi bagian penting dari narasi/teks yang diuraikan.

Separuh pertama uraian dalam buku teks ini berisi tentang pengetahuan penting mengenai positive peace, baik yang bersifat personal maupun sosial. Sejumlah sikap personal yang dapat mendukung perdamaian, di antaranya: pengendalian diri, husnudhon (prasangka baik), intiqad (introspeksi diri) dan ikhlas. Sementara itu, sikap yang bersifat sosial adalah: ukhuwah, menghargai karya orang lain dan islah. ${ }^{31}$ Sikap seperti pengendalian (self-control), berprasangka baik, introspeksi diri dan menghargai karya orang lain sebenarnya relevan dan, dalam berbagai sumber, tersurat dalam agenda peace education dalam literatur Barat. Selainnya, sikap seperti ikhlas yang biasa diartikan 'berbuat hanya karena Allah'; ukhuwah atau persaudaraan manusia atas nama ketaqwaan; dan islah, dalam sejumlah hal, memiliki kerangka konsep yang relatif khusus dalam khazanah keislaman. Atas dasar ini, asumsi bahwa nilainilai keislaman mengandung dimensi yang khas tentang upaya penegakkan perdamaian dapat dibuktikan, paling tidak secara normatif.

Dalam buku teks, sikap ikhlas bermakna kejernihan hanya untuk mengabdi kepada Allah. ${ }^{32}$ Bagi orang yang telah mencapai ini, sebagaimana dijelaskan dalam buku tersebut, tidak akan goyah dalam berbuat kebaikan dan menolak dari segala hawa nafsu dunia yang menjerumuskan seperti halnya iblis yang 
membangun "konfrontasi" terhadap Allah untuk berbuat kemungkaran. Uraian buku ini sebenarnya sangat relevan dengan pembentukan jiwa personal yang tidak mudah takluk terhadap kepentingan dunia seperti kompetisi ekonomi dan politik. Dalam sejumlah kasus, penyebab konflik bukan karena perbedaan seperti agama dan etnis tetapi karena persekongkolan ekonomi dan politik. Van Klinken ${ }^{33}$ mensinyalir bahwa konflik antar komunitas seperti antar-etnis di Kalimantan Barat dan Tengah serta antara Kristen dan Muslim di Sulawesi Tengah, Ambon dan Maluku Utara terjadi karena perseteruan politik akibat dari berbagai kepentingan politik dan ekonomi yang sangat tidak terkendali pada wilayah lokal. Oleh karena itu, uraian tentang makna penting ikhlas sebagai suasana batin pribadi Muslim merupakan sisi penting dari kandungan buku ini.

Sementara itu, ulasan tentang konsep ukhuwah menempatkan sikap sosial ini dalam khas Islam. Terma 'ukhumwah' menunjuk pada "persaudaraan antara sesama Muslim di seluruh dunia tanpa melihat perbedaan warna kulit, bahasa, suku, bangsa dan kewarganegaraan". ${ }^{34}$ Uraian selanjutnya berupa penjelasan doktrinal bahwa sikap ini merupakan perintah Allah dalam QS. Al-Hujurat ayat 10. Namun demikian, di akhir tulisan ditulis sebuah kisah penaklukan Nabi Muhammad SAW beserta pengikutnya terhadap Bani Mustaliq yang dinyatakan sebagai kelompok yang antipati terhadap Nabi dan ajaran Islam. Ini berarti bahwa kisah untuk mendukung bahwa ukhuwah merupakan persaudaraan hanya di antara Muslim kurang relevan karena ilustrasi dalam buku ini adalah bahwa Bani Mustaliq adalah kaum penentang Muslim; bukan komunitas Muslim itu sendiri. Uraian kisah semestinya relevan dan, ini akan sangat kontekstual, jika dikaitkan dengan konflik-konflik internal umat Islam sendiri di era sekarang ini. Tantangan penting lainnya, sebagaimana teoretisasi Kuntowijoyo ${ }^{35}$, adalah bagaimana umat Islam meng-'objektifikasi' atau menjadikan sikap bersaudara itu menjadi sesuatu yang wajar dan tanpa tendensi negatif bagi siapapun, termasuk bagi umat beragama lain. Sebagaimana dalam sumber lain, yang sering diklaim sebagai ide Abdurrahman Wahid, perlu dipertimbangkan konsep lainnya seperti 'ukhumwah wathaniyyah' (persaudaraan se-Negara) dan 'ukhumwah basyariyah' (persaudaraan manusia), di samping 'ukhuwwah Islamiyah' (persaudaraan se-Muslim), untuk memperkaya buku teks ini berikut dengan kisah dan kasus yang relevan.

Konsep lainnya yang dikenalkan adalah 'ishlah'. Buku ini menguraikan bahwa "ishlah atau perdamaian adalah usaha mendamaikan antara dua orang atau lebih yang bertengkar atau bermusuhan atau mendamaikan dari 
hal-hal yang dapat menimbulkan permusuhan atau peperangan. "36 Lebih lanjut dikatakan bahwa perdamaian bukan sekedar hal-hal yang bersifat kasat mata mengenai orang bisa bersahabat dengan orang lain tetapi-lagi-lagi dijelaskan sebagai bagian dari teologi agama_-perdamaian berlangsung ketika seseorang mampu dalam 'keadaan damai dengan dirinya sendiri' dan dia akan mampu melakukan itu jika dia mampu menjalin 'hubungan damai dengan Penciptanya'. ${ }^{37}$ Sampai pada penjelasan ini, sesungguhnya, pembaca-terutama siswa-perlu memperoleh bimbingan bagaimana memahami konsep ini dan, tentu saja ini bagus, bagaimana berlatih menjadikannya sebagai amalan keseharian. Konsep 'berdamai dengan diri sendiri', 'berdamai dengan Allah' dan, pada akhirnya, 'berdamai dengan orang lain' tidak mendapat porsi penjelasan yang memadai dalam buku teks ini.

Sementara itu, kisah yang disajikan di akhir bahasan ini tentang Mortenson, seorang pendaki asal Montana-Amerika, yang dapat bersahabat dengan Haji Ali, meskipun keduanya beragama dan berbudaya berbeda, cukup menarik. Sayangnya, sumber informasi kisah ini tidak disebutkan. Pada gilirannya, ungkapan bahwa setelah 'tegukan teh' terakhir mereka telah menjadi keluarga dan bersedia melakukan apa saja, termasuk mati, mungkin tidak dapat ditelusuri dengan baik sumber penjelasannya. ${ }^{38}$ Bagi pembaca atau siswa, bagian akhir dari kajian ini yakni bahwa mereka rela mati 'demi keluarga' masih dapat menimbulkan makna beragam karena dalam sejumlah hal, penjelasan ini berbeda dengan konsep ikhlas misalnya, yang menjelaskan bahwa mati dalam Islam hanya dikonseptualisasi sebagai wujud kepasrahan kepada Sang Penicipta, bukan untuk sekelompok manusia. Dengan demikian, ilustrasi tentang konsep damai dalam Islam masih perlu uraikan dengan jelas dan sinkron antara satu pemahaman dengan pemaknaan lainnya.

\section{Buku Teks Akhlak Kelas 11}

Sebagaimana dalam buku teks kelas 10, buku teks kelas 11 ini juga, dalam beberapa halaman, menampilkan gambar atau foto-foto yang tidak ada penjelasan terkait dengan bagian mana dalam suatu kalimat atau paragraf tertentu untuk gambar tersebut. Hanya saja, foto-foto dan gambar-gambar yang ada telah dibubuhi sumbernya yang berasal dari situs internet. ${ }^{39}$ Sistematika kajiannya secara umum sama yang meliputi: serambi (latar belakang), uraian yang disertai dengan dalil-dalil dan dilengkapi dengan kisah. Dibandingkan dengan muatan kelas $X$, buku teks kelas $X I$ ini relatif sedikit memiliki katakata kunci dan muatan tentang perdamaian. Buku ini secara relatif berimbang 
menyajikan kata-kata kunci yang mengandung positive peace seperti: toleransi, kerukunan dan persatuan-kesatuan serta keteladanan Rasul yang berkaitan dengan sikap damai. Sedangkan konsep negative peace dituangkan berkaitan dengan isu: kekerasan, al-qatl (pembunuhan), durhaka dan takabur (sombong). Sehingga ini dapat dikatakan bahwa muatan buku ini berkaitan dengan penumbuhan sikap hidup damai.

Dari sekian sikap sosial dalam hidup bermasyarakat yang ditunjukkan dalam buku teks ini, kajian tentang meneladani Rasul barangkali bukan sekedar menjangkau contoh-contoh sikap sosial namun juga sikap personal dalam arti sesungguhnya (intrapersonal skills) tentang bagaimana hidup damai itu ditegakkan. Buku ini secara cukup memadai menjelaskan tentang contohcontoh bagaimana Nabi Muhammad SAW membangun rumah tangganya dengan kasih sayang, memimpin umat dengan kesederhanaan dan jauh dari kepentingan pribadi-duniawi serta memberi keteladanan dengan ketinggian budi pekerti. Lebih lanjut, bagian ini mengungkapkan kisah Yahudi buta yang selalu mengolok-olok Nabi Muhammad SAW meskipun, tanpa sepengetahuannya, Muhammad kerap memberinya makan. Setelah Muhammad tiada, Yahudi ini pun baru tahu dari informasi Abu Bakar bahwa sesungguhnya yang selama ini membantunya adalah seorang Muhammad yang amat dibencinya. ${ }^{40}$ Kisah ini sangat inspiratif, meskipun tidak disebutkan sumber informasinya. Namun demikian, kisah-kisah Nabi Muhammad SAW sebenarnya banyak mengandung pesan moral untuk selalu berdamai. Khan menyebut Muhammad SAW sebagai the prophet of peace. Khan menjelaskan bahwa ketika perang Badar, Nabi Muhammad membuat sebuah skema alternatif, bukan tentang perang berikutnya (next war) tetapi "making a plan to establish future peace' (membuat rencana untuk menegakkan perdamaian di masa depan) yang didasarkan dalam QS Al-Baqarah (2) ayat 129 sebagaimana juga diterangkan dalam Ibn Katsir dalam al-Bidayah wan-Nihayah. ${ }^{41}$ Kisah tentang perang di era Nabi, sejatinya perlu dikembalikan kepada kebanggaan terhadap perlunya perdamaian, bukan permusuhan. Sayangnya pula, kisah atau contoh keteladanan hidup damai Nabi-Nabi lainnya tidak muncul dalam buku teks tersebut.

Konsep penting lainnya adalah toleransi. Buku teks ini menjelaskan bahwa toleransi (tasamuh) merupakan sikap 'memudahkan dan memberi keluasan'42 dalam berinteraksi di tengah perbedaan. Prinsip-prinsip yang dituangkan dalam buku tersebut adalah bahwa seorang Muslim perlu menghargai perbedaan, tidak mengolok-olok orang lain dengan sebutan 'kafir' dan tidak alasan untuk 
berdakwah dengan jalan kekerasan. Selanjutnya, kisah yang disampaikan melalui kajian ini adalah penghormatan Nabi Muhammad dengan berdiri terhadap iring-iringan jenazah Yahudi. ${ }^{43}$ Penjelasan tersebut secara konseptual memadai meskipun memerlukan contoh-contoh aktual tentang kehidupan bermasyarakat dan bernegara dewasa ini yang, dalam sejumlah kasus, sikap toleran kurang tumbuh secara merata.

Sejalan dengan konsep toleransi, sebagaimana yang dituangkan dalam buku ini, konsep lainnya seperti kerukunan, persatuan dan kesatuan (unity) menjadi penting. Sebagaimana dalam berbagai literatur lainnya, contoh persaudaraan antara kaum Ansar dan Muhajirin serta perjuangan Nabi Muhammad menyusun Piagam Madinah dengan mengajak beberapa suku dan penganut Yahudi serta suku-suku lainnya, merupakan contoh historis tentang bagaimana kerukunan itu mencoba dibangun. Kisah lainnya yang dinukil dalam buku teks ini adalah kisah seorang Yahudi yang tinggal di kediaman Nabi Muhammad SAW meskipun tanpa penyebutan sumber pengutipan ceritanya. ${ }^{44}$ Pemaparan tersebut menunjukkan bahwa sejarah umat Islam sejatinya memiliki kekayaan spiritual tentang bagaimana kerukunan itu ditegakkan. Kerukunan di sini digambarkan sebagai kesediaan menerima perbedaan di sekelilingnya, tanpa larut meninggalkan identitas personal maupun komunitasnya, serta memiliki sikap bersedia untuk membangun kesepakatan (agreement) mengenai hal-hal apa saja yang bisa disepakati pada level kehidupan bersama. Contoh keindonesiaan seperti halnya Piagam Jakarta dan Pancasila sebenarnya dapat dilihat sebagai contoh kekinian tentang bagaimana antar-komunitas menjalin kesepakatan sebagaimana ketika Nabi SAW melakukannya. Analogi seperti ini sepertinya perlu ditelaah dalam buku ini.

Isu spesifik terkait dengan konsep 'kerukunan' yang diajarkan di kelas XI dan konsep 'ukhuwwah' di kelas X barangkali perlu diklarifikasi. Apakah secara maknawi kedua konsep itu berbeda sehingga perlu diulang kembali. Pengulangan materi ini sepertinya berkaitan dengan penjelasan dari buku teks Kelas X bahwa makna 'ukhuwwah' hanya berkaitan dengan relasi antar-Muslim. Sedangkan konsep 'kerukunan' di buku teks Kelas XI meliputi dua lapis, yakni: 'kerukunan sesama umat beragama' dan 'kerukunan antar-umat beragama' ${ }^{45}$ Bila ditelaah secara konsep, makna ukhumwah sebenarnya juga 'kerukunan' atau 'persaudaraan' itu sendiri. Kerukunan yang dimaksud dapat dibatasi oleh agama tertentu, termasuk Muslim secara internal, maupun antaragama dan bahkan, secara luas, antar-Negara. Jangkauan kerukunan inilah 
yang sebenarnya perlu dibangun kembali hingga dalam level global. Seorang Profesor International Education di Universitas Birmingham, Inggris, Davies ${ }^{46}$ misalnya menyatakan tentang perlunya wawasan global mengenai kewargaan (global citizenship) untuk mengurangi pemahaman dan relasi sosial yang tidak bersahabat antara satu bangsa dengan bangsa lainnya. Penguatan misi ini sejalan dengan konsep 'rahmatan lil'alamin' atau spirit 'Islam untuk semua' yang perlu diajarkan secara intensif dan aplikatif kepada para siswa.

Di samping itu, buku teks ini juga menuangkan konsep persatuan dan kesatuan (unity). Di sana dinyatakan bahwa konsep ini diartikan sebagai ikatan kesamaan dengan menyisihkan perbedaan. Kesamaan diutamakan daripada perbedaannya. Di akhir kajiannya, buku teks ini mengisahkan kegagalan pasukan Muslim dalam Perang Uhud yang disebabkan oleh ketidaktaatan sebagian pasukan pemanah untuk tetap berada di posisinya karena tergiur ingin memperoleh harta rampasan perang ${ }^{47}$ Pesan yang tampak dari muatan teks ini adalah bahwa pertama, pengarus-utamaan persamaan di tengah masyarakat menjadi penting agar kebersamaan tetap terjalin. Kedua, ancaman atas praktek persatuan ini adalah kompetisi dan perebutan ekonomi dan kekuasaan. Secara sosial, Hefner pernah mencatat bahwa perbedaan yang bersifat vertikal yakni antara penguasa dan rakyat serta perbedaan yang bersifat horisontal seperti perbedaan agama, ras, suku, bahasa dan kebiasaan-kebiasaan sosial lainnya dapat memicu konflik. ${ }^{48}$ Sekali lagi, pangarus-utamaan persatuan penting dengan tetap menjaga sikap apresiasi terhadap keragaman. Di sisi yang sama, penghargaan terhadap persamaan perlu dijadikan sebagai metode atau jalan saja untuk mencapai kebersamaan, bukan dengan menjadikannya tujuan. Karena apabila persamaan dijadikan sebagai tujuan maka fakta tentang pembasmian etnis yang berbeda (genocide) menjadi ancaman terburuk yang dapat saja terjadi. Temuan ${ }^{49}$ mengenai adanya upaya pembasmian komunitas di Indonesia dewasa ini sekiranya patut menjadi alarm (peringatan) untuk pencegahan melalui pendidikan perdamaian yang berkelanjutan mengenai penempatan identitas publik secara tepat antara identitas yang sama dan yang berbeda.

\section{Buku Teks Akhlak Kelas 12}

Seperti halnya buku teks di kelas lebih rendah, buku teks Kelas 12 ini juga menyajikan materi dengan sistematika dimulai dari serambi (latar belakang), uraian yang disertai dengan dalil-dalil dan diakhiri dengan kisah. Keseluruhan gambar yang ditampilkan memiliki referensi meskipun, lagi-lagi, tidak diikuti 
dengan penjelasan dalam kalimat atau paragraf berkenaan dengan gambargambar yang ditampilkan. Hal lainnya adalah munculnya ketidak-hati-hatian penulis dengan menampilkan gambar yang sama sebagaimana ada dalam halaman $16^{50}$ dengan buku teks Kelas $X$ di halaman 64. Di antara isu-isu penting yang akan diulas dalam kajian ini adalah menumbuhkan sikap kritis, musyawarah dan sikap positif terhadap lingkungan, yang di antaranya telah tertulis dalam buku teks Kelas 12 ini.

Tidak ada penjelasan tentang mengapa berfikir kritis dituangkan dalam buku teks Akhlak Kelas 12 ini. Namun jika dibaca dari definisi, berfikir kritis yang dimaksud adalah sikap 'tidak lekas percaya' serta 'sifat yang selalu bersusaha menemukan kesalahan, kekeliruan atau kekurangan'. Buku teks ini menyatakan bahwa:

"Kritik yang diperbolehkan oleh agama Islam adalah kritik yang sehat, yang didasari dengan niat ikhlas karena Allah SWT, tidak menggunakan kata-kata yang pedas yang menyakiti hati, dan dengan maksud untuk memberikan bantuan atau pertolongan kepada orang yang dikritik agar menyadari kesalahannya dan kekurangannya, dengan memberikan petunjuk tentang jalan keluar dari kesalahan ..." "51

Berdasarkan kutipan di atas, makna penting sikap kritis adalah untuk membentuk sikap personal yang hati-hati terhadap berbagai informasi dan, pada saat yang berbeda, dapat pula memberikan masukan terhadap orang lain mengenai berbagai informasi dan perilaku yang telah dipercayainya bahwa terdapat sumber pengetahuan yang belum tentu benar. Meskipun kajian dalam buku teks tersebut tidak dijelaskan secara memadai apa kegunakan praktis dari berfikir kritis, konsep berfikir kritis sejatinya telah di-endorse untuk menjadi jalan bagi seseorang agar tidak mudah terombang-ambing terhadap berbagai pengetahuan yang berpotensi menyimpang. Karya Davies, Educating Against Extremism, ${ }^{52}$ telah menekankan betapa pentingnya konsep dan praktek berfikir kritis untuk mengimbangi kebiasaan berfikir tanpa dasar argumen yang jelas, seperti perilaku kekerasan yang mencoba dicarikan pembenarannya secara serampangan melalui tafsir atas doktrin keagamaan atau argumen personal serta kelompok tertentu. Berfikir kritis pada dasarnya merekomendasikan bahwa dalam mengambil informasi dan keputusan, siswa dididik untuk menelaah berbagai sumber informasi terlebih dahulu sebelum menentukan sikap dan pandangan. Sikap hati-hati seperti ini merupakan sikap personal yang perlu ditumbuhkan pada setiap pribadi Muslim. 
Konsep penting lainnya dalam mencegah konflik dengan kekerasan dan menjaga kelangsungan perdamaian adalah musyawarah. Buku teks ini menguraikan bahwa musyawarah merupakan jalan untuk 'saling menjelaskan dan merundingkan, serta saling tukar-pendapat tentang suatu persoalan' ${ }^{53}$ Dengan mendasarkan pada pandangan Ilyas (2009), buku teks ini menjelaskan bahwa wilayah yang bisa dimusyawarahkan di kalangan Muslim adalah halhal yang tidak secara rinci diatur atau di luar ibadah khusus seperti shalat, zakat, puasa, haji yang sebenarnya juga termasuk bab keimanan (belief). Di luar wilayah itu, sebagaimana ditekankan pada muatan buku ini, terbuka peluang dilakukan musyawarah. Sebagai sebuah buku ajar, buku ini sebenarnya bisa dikembangkan dengan contoh-contoh keseharian siswa tentang praktek bermusyawarah, penyelesaian sengketa siswa melalui musyawarah, dan berbagai perilaku kolektif yang positif lainnya.

Satu sikap sosial lainnya yang penting, sebagaimana diarahkan de Rivera ${ }^{54}$, adalah peduli terhadap lingkungan. Dalam buku teks ini, lingkungan didefinsikan sebagai 'segala sesuatu yang berada di sekitar manusia, baik tumbuh-tumbuhan, binatang maupun benda-benda tak bernyawa. ${ }^{55}$ Sebagai bagian dari akhlak terhadap lingkungan, buku teks ini menguraikan bahwa manusia semestinya melakukan konservasi ekologis dan mencegah kerusakan lingkungan serta melakukan upaya penegakkan kebaikan dan mencegah kemungkaran atas praktek-praktek keserakahan dan kebijakan yang mengabaikan kelangsungan lingkungan. ${ }^{56}$ Uraian teoretik dalam buku tersebut sudah cukup memadai yang di antaranya dengan mengacu pada dalil-dalil Al-Qur'an dan kompilasi substansi ajaran dalam Pedoman Hidup Islami Warga Muhammadiyah (PHIWM). Hanya saja, contoh-contoh gamblang tentang praktek perusakan lingkungan, baik secara personal dilakukan oleh oknum maupun kelembagaan yang dilakukan oleh izin terhadap perusahaan swasta melakukan pemanfaatan lingkungan tanpa terkendali, sekiranya perlu ditulis dengan memadai. Pemahaman yang utuh seperti ini diharapkan akan menjadi upaya penyadaran kontekstual. Dalam pandangan de Rivera, relasi yang harmoni dengan lingkungan merupakan bagian penting pendidikan perdamaian dewasa ini. Lingkungan merupakan penyedia modal sosial, ekonomi dan fisik yang penting. Jika tindakan dan kesepakatan atas pengelolaan alam untuk kelangsungan hidup di masa kini dan masa depan yang lebih harmonis tidak dilakukan maka manusia dengan sendirinya tengah berada di ambang kehancuran. 


\section{KESIMPULAN}

Kebutuhan untuk mentransformasikan nilai-nilai atau sikap hidup damai di lingkungan pendidikan cukup penting dalam kerangka untuk meng-counter paham dan perilaku pro-kekerasan serta untuk menegakkan perdamaian dalam payung keadilan. Dengan menganalisis buku teks Akhlak di sekolah Muhammadiyah, buku teks seperti ini dapat menjadi medium untuk penyemaiam nilai-nilai perdamaian. Tulisan ini menemukan bahwa buku teks Pendidikan Akhlak —sebagai bagian dari Pendidikan Agama Islam—secara umum menyajikan berbagai nilai positif untuk menumbuhkan dan melanggengkan perdamaian. Sementara itu, pengetahuan untuk mencegah dan mengatasi potensi dan aktualisasi konflik dan kekerasan juga ditulis secara hampir merata di semua level kelas/semester. Namun demikian, secara konten, buku teks ini mengandung sejumlah keterbatasan antara lain: pertama, aspek kedalaman materi, yakni berkenaan dengan keterbatasan wawasan kontekstual atau contohcontoh yang memadai yang diambilkan dari keseharian. Kedua, penyajian beberapa gambar atau foto yang tidak dikaitkan dengan penjelasan dalam kalimat atau paragraf yang sesuai. Ketiga, sistem pengutipan (referencing) yang belum memadai berkaitan dengan konten maupun gambar yang dipilih. Keempat, aspek koherensi yakni konsistensi dan kemenyeluruhan konsep dan analisis tentang nilai-nilai yang berkaitan dengan sikap hidup damai yang kurang memadai. Atas dasar ini, maka perbaikan dan pendalaman telaah atas konten yang berkaitan dengan ide-ide dan nilai-nilai perdamaian dalam buku teks ini menjadi penting agar siswa diharapkan dapat memperoleh wawasan yang komprehensif. Wawasan yang lengkap atas ide dan sikap hidup damai tersebut merupakan modal penting baginya untuk menjadi subjek yang positif dan aktif dalam menegakkan perdamaian.

\section{CATATAN AKHIR}

1 Tulisan ini merupakan bagian dari Penelitian Unggulan Program Studi yang dibiayai oleh LP3M Universitas Muhammadiyah Yogyakarta. Alamat korespondensi: nurwanto@umy.ac.id

2 Khaeruddin, dkk, Kurikulum Tingkat Satuan Pendidikan Pendidikan: Konsep dan Implementasinya di Madrasah (Yogyakarta: Madrasah Development Center Jawa Tengah dan Pilar Media, 2007), h. 329-359.

3 Lihat lebih lanjut dalam Permendiknas No. 23 Tahun 2003 yang terutama berkaitan dengan 6 (enam) Standar Kompetensi Kelompok Mata Pelajaran (SK-KMP).

4 Hasballah, Perkelahian Pelajar: Potret Siswa SMU di DKI Jakarta (Jakarta: Galang 
Press, 2003), h. 114.

5 Harber C dan Sakade N, Schooling for violence and peace: how does peace education differ from 'normal' schooling? Journal of Peace Education, Vol. 6. No. 2. September (2009), p. 171-187.

6 Davies L, "Schools and war: urgent agendas for comparative and international education”, Compare, Vol. 35. No. 4. December (2005), p. 57-371.

7 Davies Lynn, Educating Against Extremism (USA: Trentham Books Limited, 2008)

8 Muthali'in A, Bias Gender dalam Pendidikan (Surakarta: Muhammadiyah University Press, 2001).

9 Nurwanto, "The Portrait of gender justice and injustice in the Islamic teaching teaxtbook and Muhammadiyah teachers' responses”, Indonesian Journal of Islam and Muslim Societies, Vol. 3, No. 1. June (2013), h. 149-173.

10 Khan M. W, The Prophet of Peace: Teachings of the Prophet Muhammad (India: Penguin Books, 2009).

11 Köylü M, "Peace education: an Islamic approach", Journal of Peace Education, Vol.1. No.1. (2004), p. 59 - 76.

12 De Rivera, J. "Assessing the Peacefulness of Cultures” dalam de Rivera, J. (Ed.). Handbook on Building Cultures of Peace. USA: Springer, 2009, hal. 89.

13 Fell, G. "Peace" dalam Hicks, D. Education for Peace: Issues, Principles and Practice in the Classroom. London: Routledge, 1998, hal. 72

14 Concise Oxford English Dictionary, Eleventh Edition. Oxford: Oxford University Press, 2004 (Format CD).

15 De Rivera J., "Assessing the Peacefulness of Cultures" dalam de Rivera J. (Ed.) Handbook on Building Cultures of Peace (USA: Springer, 2009), h. 89.

16 Fell G, "Peace" dalam Hicks D, Education for Peace: Issues, Principles and Practice in the Classroom (London: Routledge, 1998), h. 72.

17 Teori dan praktek mengenai bagaimana perdamaian dapat dibangun dari proses komunikasi, misalnya melalui Non-Violence Communication (NVC). Rosenberg M B., Speak Peace in a World of Conflict (USA: PuddleDancer Press Book, 2005).

18 Misalnya dapat dilihat dalam Musfiroh et.al., Afiliasi dan Resolusi Konflik (Yogyakarta: Pusat Studi PAUD UNY, 2007).

19 Wawancara dengan Tim Pengembang Kurikulum ISMUBA Majelis Dikdasmen PWM DIY, 20/2/2015.

20 Tim Pengembang Kurikulum, Kurikulum Pendidikan Al-Islam, Kemuhammadiyahan dan Bahasa Arab (ISMUBA) SMA/SMK/MA Muhammadiyah (Yogyakarta: Majelis Dikdasmen PWM DIY, 2012), h. 2.

21 Tim Pengembang Kurikulum, Kurikulum Pendidikan Al-slam, Kemuhammadiyahan dan Bahasa Arab (ISMUBA) SMA/SMK/MA Muhammadiyah (Yogyakarta: Majelis Dikdasmen PWM DIY, 2012), h. 2.

22 Tim Pengembang Kurikulum, Kurikulum Pendidikan Al-Islam, Kemuhammadiyahan dan Bahasa Arab (ISMUBA) SMA/SMK/MA Muhammadiyah (Yogyakarta: Majelis Dikdasmen PWM DIY, 2012), h. 4.

23 Lihat Sairin W., Referensi Yuridis (Peraturan Perundang-Undangan) Kurikulum 2013 (Bandung: Yrama Widya, 2014). 

Handbook on Building Cultures of Peace (USA: Springer, 2009), h. 89.; Fell G., "Peace" dalam Hicks D., Education for Peace: Issues, Principles and Practice in the Classroom (London: Routledge, 1998), p. 72.

25 Lihat: Permendikbud No. 54 Tahun 2013 Tentang Standar Kompetensi Lulusan Pendidikan Dasar dan Menengah.

26 Tim Pengembang Kurikulum, Kurikulum Pendidikan Al-Islam, Kemuhammadiyahan dan Bahasa Arab (ISMUBA) SMA/SMK/MA Muhammadiyah (Yogyakarta: Majelis Dikdasmen PWM DIY, 2012), h. 11.

27 De Rivera J., "Assessing the Peacefulness of Cultures" dalam de Rivera, J. (Ed.). Handbook on Building Cultures of Peace, (USA: Springer, 2009), h. 89.; Fell G., "Peace" dalam Hicks D., Education for Peace: Issues, Principles and Practice in the Classroom (London: Routledge, 1998), h.72.

28 Penjelasan tentang hirarki kompetensi dalam Kurikulum 2006 ini misalnya dapat dilihat dalam Khaeruddin dan Junaedi M., Kurikulum Tingkat Satuan Pendidikan: Konsep dan Implementasinya di Madrasah (Yogyakarta: MDC Jateng dan Pilar Media, 2007) ; Muslich M., KTSP: Dasar Pemahaman dan Pengembangan Cetakan Kelima (Jakarta: Bumi Aksara, 2009).

29 Khan M. W., The Prophet of Peace: Teachings of the Prophet Muhammad (India: Penguin Books, 2009).

30 Lihat Jannah A.N., Pendidikan Akhlak SMA/SMK/MA Muhammadiyah Kelas 10 (Yogyakarta: Majelis Dikdasmen PWM DIY, 2014), h. 2. Gambar-gambar lain yang tidak dituliskan sumbernya dan penjelasannya misalnya di halaman 14 , 18, 20, 26, 28, dan seterusnya.

31 Lihat Jannah A.N., Pendidikan Akhlak SMA/SMK/MA Muhammadiyah Kelas 10 (Yogyakarta: Majelis Dikdasmen PWM DIY, 2014), h. 1-83.

32 Lihat Jannah A.N., Pendidikan Akhlak SMA/SMK/MA Muhammadiyah Kelas 10 (Yogyakarta: Majelis Dikdasmen PWM DIY, 2014), h. 50.

33 Van Klinken G., Perang Kota Kecil: Kekerasan Komunal dan Demokratisasi di Indonesia (Jakarta: Yayasan Obor Indonesia dan KITLV-Jakarta, 2007).

34 Jannah A.N., Pendidikan Akhlak SMA/SMK/MA Muhammadiyah Kelas 10 (Yogyakarta: Majelis Dikdasmen PWM DIY, 2014), h. 20.

35 Kuntowijoyo, Muslim Tanpa Masjid (Bandung: Mizan, 1997).

36 Jannah A.N., Pendidikan Akhlak SMA/SMK/MA Muhammadiyah Kelas 10 (Yogyakarta: Majelis Dikdasmen PWM DIY, 2014), h. 76

37 Jannah A.N., Pendidikan Akhlak SMA/SMK/MA Muhammadiyah Kelas 10 (Yogyakarta: Majelis Dikdasmen PWM DIY, 2014, h. 78.

38 Jannah A.N., Pendidikan Akhlak SMA/SMK/MA Muhammadiyah Kelas 10 (Yogyakarta: Majelis Dikdasmen PWM DIY, 2014), h. 80-82.

39 Abdur Rozaq M., Pendidikan Akhlak SMA/SMK/MA Muhammadiyah Kelas 11 (Yogyakarta: Majelis Dikdasmen PWM DIY, 2014), h. 2. Gambar-gambar yang disajikan misalnya dapat dilihat di halaman 3, 10, 62, 68, 70, 76, 81, dan seterusnya.

40 Abdur Rozaq M., Pendidikan Akhlak SMA/SMK/MA Muhammadiyah Kelas 11 
(Yogyakarta: Majelis Dikdasmen PWM DIY, 2014), h. 66-67.

${ }^{41}$ Khan M.W., The Prophet of Peace: Teachings of the Prophet Muhammad (India: Penguin Books, 2009), h. 28.

42 Abdur Rozaq M., Pendidikan Akhlak SMA/SMK/MA Muhammadiyah Kelas 11 (Yogyakarta: Majelis Dikdasmen PWM DIY, 2014), h. 70.

43 Abdur Rozaq M., Pendidikan Akhlak SMA/SMK/MA Muhammadiyah Kelas 11 (Yogyakarta: Majelis Dikdasmen PWM DIY, 2014), h. 71-73.

44 Abdur Rozaq M., Pendidikan Akhlak SMA/SMK/MA Muhammadiyah Kelas 11 (Yogyakarta: Majelis Dikdasmen PWM DIY, 2014), h. 79-80.

45 Abdur Rozaq M., Pendidikan Akhlak SMA/SMK/MA Muhammadiyah Kelas 11 (Yogyakarta: Majelis Dikdasmen PWM DIY, 2014), h. 76-78.

46 Davies L., Global citizenship: abstraction or framework for action?, Educational Review, 58 (1), (2006), h. 5-25.

47 Abdur Rozaq M., Pendidikan Akhlak SMA/SMK/MA Muhammadiyah Kelas 11 (Yogyakarta: Majelis Dikdasmen PWM DIY, 2014), h. 84-88.

48 Lihat Asykuri (Ed.), Civic Education, Pendidikan Kewarganegaraan, Menuju Kehidupan yang Demkratis dan Berkeadaban (Yogyakarta: LP3M UMY dan The Asia Foundation, 2003).

49 Bisa ditelusuri dalam Van Klinken, G., (2007) ; Soeharto B., Menangani Konflik di Indonesia (Jakarta: Kasta Hasta Pustaka, 2013).

50 Margito dan Abdur Rozaq M., Pendidikan Akhlak SMA/SMK/MA Muhammadiyah Kelas 12 (Yogyakarta: Majelis Dikdasmen PWM DIY, 2014).

51 Margito dan Abdur Rozaq M., Pendidikan Akhlak SMA/SMK/MA Muhammadiyah Kelas 12 (Yogyakarta: Majelis Dikdasmen PWM DIY, 2014), h. 2.

52 Lihat detail dalam buku Davies L., Educating Against Extremism (England: Trentham Books Limited, 2008), h. 173.

53 Margito dan Abdur Rozaq M., Pendidikan Akhlak SMA/SMK/MA Muhammadiyah Kelas 12 (Yogyakarta: Majelis Dikdasmen PWM DIY, 2014), h. 134.

54 De Rivera, "Assessing the Peacefulness of Cultures" dalam de Rivera, J. (Ed.), Handbook on Building Cultures of Peace (USA: Springer, 2009), h. 89.

55 Margito dan Abdur Rozaq M., Pendidikan Akhlak SMA/SMK/MA Muhammadiyah Kelas 12 (Yogyakarta: Majelis Dikdasmen PWM DIY, 2014), h. 60.

56 Margito dan Abdur Rozaq M., Pendidikan Akhlak SMA/SMK/MA Muhammadiyah Kelas 12 (Yogyakarta: Majelis Dikdasmen PWM DIY, 2014), h. 65-67.

\section{DAFTAR PUSTAKA}

Abdur Rozaq, Muhammad. 2014. Pendidikan Akhlak SMA/SMK/MA Muhammadiyah Kelas 11, Yogyakarta: Majelis Dikdasmen PWM DIY.

Davies, L. 2006. Global citizenship: abstraction or framework for action?, Educational Review, 58 (1), hal. 5-25.

Davies, L. 2005. "Schools and war: urgent agendas for comparative and international education”, Compare, Vol. 35, No. 4, December, hal. 57-371.

Davies, L. 2008. Educating Against Extremism, USA: Trentham Books Limited.

De Rivera, J. 2009. "Assessing the Peacefulness of Cultures” dalam de Rivera, J. 
(Ed.). Handbook on Building Cultures of Peace, USA: Springer.

Fell, G. 1998. "Peace" dalam Hicks, D. Education for Peace: Issues, Principles and Practice in the Classroom, London: Routledge.

Harber, C dan Sakade, N. 2009. Schooling for violence and peace: how does peace education differ from 'normal' schooling? Journal of Peace Education, Vol. 6 (2), September, h. 171-187.

Hasballah, 2003. Perkelahian Pelajar: Potret Siswa SMU di DKI Jakarta, Jakarta: Galang Press.

Jannah, A.N. 2014. Pendidikan Akhlak SMA/SMK/MA Muhammadiyah Kelas 10, Yogyakarta: Majelis Dikdasmen PWM DIY.

Khaeruddin dan Junaedi, M. 2007. Kurikulum Tingkat Satuan Pendidikan: Konsep dan Implementasinya di Madrasah, Ygyakarta: MDC Jateng dan Pilar Media.

Khan, M. W. 2009. The Prophet of Peace: Teachings of the Prophet Muhammad, India: Penguin Books.

Margito dan Abdur Rozaq, M. 2014. Pendidikan Akhlak SMA/SMK/MA Muhammadiyah Kelas 12, Yogyakarta: Majelis Dikdasmen PWM DIY.

Muslich, M. 2009. KTSP: Dasar Pemahaman dan Pengembangan Cetakan Kelima, Jakarta: Bumi Aksara.

Muthali'in, A. 2001. Bias Gender dalam Pendidikan, Surakarta: Muhammadiyah University Press.

Nurwanto. 2013. "The Portrait of gender justice and injustice in the Islamic teaching teaxtbook and Muhammadiyah teachers' responses”, Indonesian Journal of Islam and Muslim Societies, Vol. 3 (1), June, hal. 149-173.

Sairin, W. 2014. Referensi Yuridis (Peraturan Perundang-Undangan) Kurikulum 2013, Bandung: Yrama Widya.

Soeharto, B. 2013. Menangani Konflik di Indonesia, Jakarta: Kasta Hasta Pustaka.

Tim Pengembang Kurikulum. 2012. Kurikulum Pendidikan Al-Islam, Kemuhammadiyahan dan Bahasa Arab (ISMUBA) SMA/SMK/MA Muhammadiyah, Yogyakarta: Majelis Dikdasmen PWM DIY.

van Klinken, G. 2007. Perang Kota Kecil: Kekerasan Komunal dan Demokratisasi di Indonesia, Jakarta: Yayasan Obor Indonesia dan KITLV-Jakarta. 